\title{
Detection and characterization of Genogroup 5 Rotavirus associated with piglet diarrhoea in the North East Region of India
}

\author{
Hosterson Kylla, Tapan K. Dutta*, Parimal Roychoudhury, \\ Rajkumari Mandakini, and Prashant K. Subudhi
}

Department of Veterinary Microbiology, Central Agricultural University, Selesih, Aizawl, Mizoram, India

KYLLA, H., T. K. DUTTA, P. ROYCHOUDHURY, R. MANDAKINI, P. K. SUBUDH: Detection and characterization of Genogroup 5 Rotavirus associated with piglet diarrhoea in the North East Region of India. Vet. arhiv 88, 453-466, 2018.

ABSTRACT

Rotaviruses have been recognized as an important etiological agent of non-bacterial acute gastroenteritis in young children and animals of several species worldwide, including diarrhoea in weaning and post-weaning piglets. In this study, we report the prevalence and molecular epidemiology of rotaviruses detected from piglets in different regions of the north-eastern hilly region of India. A total of 457 faecal samples (339 diarrhoeal and 118 non-diarrhoeal) were collected from piglets from local $(n=130)$ and cross breed $(n=327)$ piglets between July 2013 to June 2015 in different seasons of the year. All the samples were subjected to RNA-PAGE and RTPCR analysis. Rotaviruses were detected in $4.81 \%$ animals by RNA-PAGE and $7.43 \%$ animals by RT-PCR, with the highest prevalence (9.67\%) from Meghalaya state. All the isolates were recorded as GARV and genogroup 5. The prevalence was higher in unorganized farms $(10.77 \%)$ compared to organized farms $(4.0 \%)$ with higher detection from diarrhoeic $(9.14 \%)$ compared to non-diarrhoeic animals $(2.54 \%)$. A higher prevalence was also recorded during the summer (12.5\%) and winter (9.09\%) seasons. On the basis of the sequence analysis, all the isolates were placed in a unique single cluster, different from other Indian isolates from humans and animals, which were in close proximity with human isolates. This is the first report of the detection of G5 Rotavirus associated with piglet diarrhoea in India.

Key words: Rotavirus; prevalence; genogroup 5; piglets; India

\section{Introduction}

Rotavirus, a member of the Reoviridae family, is a major aetiological agent of acute non-bacterial gastroenteritis in a wide variety of young mammalian and avian species (JUNAID et al., 2011; WAKUDA et al., 2011). Rotavirus infection frequently occurs in nursing pigs at 1 to 5 weeks of age, with a peak incidence at 1 to 3 weeks, and again at

\footnotetext{
${ }^{*}$ Corresponding author:

Dr. Tapan Kumar Dutta, Professor \& Head, Department of Veterinary Microbiology, Central Agricultural University, Selesih, Aizawl, Mizoram - 796014. India, E-mail: tapandutta@rediffmail.com
} 
about 2 to 7 days post weaning (CASTRO and HEUSCHELE, 1992). The viral genome consists of eleven segments; each segment is a gene, numbered 1 to 11 by decreasing size. Each gene codes for one protein, except gene 11, which codes for two proteins, viz., NSP5 and NSP6 (CHAN et al., 1986). There are 6 structural proteins (VP1, VP2, VP3, VP4, VP6 and VP7) and six non-structural proteins (NSP1 to NSP6) (LORROT and VASSEUR, 2007; WILHELMI et al., 2003). On the basis of the antigenic properties of the VP6 protein, rotaviruses have been divided into 5 serological groups (A-E) and two additional tentative groups ( $F$ and $G$ ) (MATTHIJNSSENS et al., 2011). Of these seven groups, only groups $\mathrm{A}, \mathrm{B}$ and $\mathrm{C}$ are known to infect humans and animals, whereas, group D, E, F and G are found only in animals, mostly birds (BROOR et al., 2003). Another group $\mathrm{H}$ has been added to the existing seven groups of Rotavirus, which was initially identified in humans (YANG et al., 2004) and later on classified as group H (MATTHIJNSSENS et al., 2011). A group H-like rotavirus has also been detected in pigs (WAKUDA et al., 2011). Group A rotaviruses are most often responsible for diarrhoea in piglets (HALAIHEL et al., 2010; LINARES et al., 2009; MARTELLA et al., 2007; WINIARCZYK et al., 2002). However, rotaviruses such as groups B and C may also be responsible for episodes of diarrhoea in piglets (MARTELLA et al., 2007; SAIF and JIANG, 1994). Rotavirus strains are classified into VP4 or P serotypes (P for proteasesensitive) and VP7 or G serotypes ( $\mathrm{G}$ for glycoprotein). Epidemiological studies of porcine rotaviruses in several countries have identified at least four main G types - G3, G4, G5 and G11, which are the most common (ESTES, 2001). However, other porcine rotaviruses, such as G1, G2, G6, G8, G9 and G10, have also been reported occasionally. $\mathrm{P}[6]$ and $\mathrm{P}[7]$ were found to be the most common $\mathrm{P}$ genotypes in porcine, while $\mathrm{P}[13]$, $\mathrm{P}[14], \mathrm{P}[19], \mathrm{P}[23]$ and $\mathrm{P}[26]$ were seldom reported [24]. In India, 4 types of G (G4, G6, G9, G12) and 4 types of P genotypes (P [6], P [7], P [13], P [19]) of rotaviruses have been detected from pigs so far (MALIK et al., 2014).

The North East Hilly Region of India is mainly inhabited by tribal populations, where pig farming is an integral part of life and a significant source of income, with the highest pig population (3.95 million) in India (19 ${ }^{\text {th }}$ Livestock census 2012$)$. Porcine viral gastroenteritis is one of the most common diseases affecting the piggery industry in this region. In the present study, an attempt had been made to understand the prevalence of Rotavirus in piglets (below 3 months of age) with or without diarrhoea, and molecular characterization of porcine Rotavirus in the North Eastern Hilly Region of India.

\section{Materials and methods}

Collection of faecal samples. A total of 457 fresh faecal samples were collected from piglets $(<3$ months) from organized $(n=225)$ and unorganized $(n=232)$ farms of 4 North Eastern Hilly states of India, viz., Manipur $(\mathrm{n}=108)$, Meghalaya $(\mathrm{n}=124)$, Mizoram $(\mathrm{n}=$ $120)$ and Nagaland $(n=105)$. Samples were collected from diarrhoeic $(n=339)$ and nondiarrhoeic $(n=118)$ piglets included indigenous local $(n=130)$ and cross breed (LWY 
H. Kylla et al.: Detection and characterization of Genogroup 5 Rotavirus associated with piglet diarrhoea in the North East Region of India

$\mathrm{x}$ local germ plasma) $(\mathrm{n}=327)$ piglets (Table 1). Samples were collected in 4 different seasons of the year, viz., spring (March-May) $(\mathrm{n}=93)$, summer (June-August) $(\mathrm{n}=128)$, autumn (September-November) $(\mathrm{n}=104)$ and winter (December-February) $(\mathrm{n}=132)$ from June 2014 to May 2016.

Sample processing and extraction of viral nucleic acids. A 10\% suspension of each faecal sample was prepared with phosphate buffered saline (PBS; $\mathrm{pH} 7.4$ ) by dissolving 0.1 gram of faeces in $1 \mathrm{~mL}$ PBS. The suspension was vortexed for $2 \mathrm{~min}$, followed by centrifugation at $10,000 \mathrm{rpm}$ for $20 \mathrm{~min}$ at $4{ }^{\circ} \mathrm{C}$ to remove the course debris. The clarified supernatant was collected and stored at $4{ }^{\circ} \mathrm{C}$ for short term storage, and $-20{ }^{\circ} \mathrm{C}$ or $-80{ }^{\circ} \mathrm{C}$ for longer term. RNA was extracted from the supernatant of the faecal samples by the Trizol extraction method, as per the WHO Manual (2009). The quality, quantity and purity of the total RNA was checked in a Nanodrop Spectrophotometer (Thermo Scientific, USA).

Detection of dsRNA of Rotavirus by RNA-PAGE. Electrophoresis of the viral RNA was carried out (MALIK et al., 2014) in 10\% native (non-denaturing) polyacrylamide gel in Tris-Glycine buffer (0.025 M Tris, $0.109 \mathrm{M}$ Glycine, $\mathrm{pH} 8.3$ ) by loading up to $500 \mathrm{ng}$ of viral RNA per well. The viral genomic electrophoresis was also carried out in denaturing $5 \%$ polyacrylamide gel (containing $7 \mathrm{M}$ Urea) in $1 \times \mathrm{TBE}$ running buffer $(8.9 \mathrm{mM}$ Tris, $8.9 \mathrm{mM}$ Boric acid, $0.2 \mathrm{mM}$ EDTA, $\mathrm{pH} 8.3$ ) by loading the same amount of viral RNA per well. Samples were electrophorosed at $100 \mathrm{~V}$ until the dye reached the end of the gel (approx. $4 \mathrm{~h}$ ). The gel was silver impregnated and documented. For estimation of the molecular weight of the segments of Rotavirus, samples were run with group A Rotavirus and $1 \mathrm{kbps}$ DNA ladder (Fermentas) on $1 \times$ agarose gel, stained with ethidium bromide and documented in the Gel doc system (Alpha Image, USA).

Detection of Rotavirus by RT-PCR. Characterization of rotavirus was done by RT-PCR targeting VP7 gene segment for Group A Rotavirus (F: TTGACTAARGGRTGGCCAACWGG; R: TCGCATCATHCKYTCNGTTT GTGG) and VP6 gene segment for Group C Rotavirus (GABBAY et al., 2008). The PCR was conducted in a thin walled PCR tube in a total volume of $25 \mu \mathrm{L}$, containing $1 \times$ PCR buffer, $1.5 \mathrm{mM} \mathrm{MgCl}, 200 \mu \mathrm{M}$ of each dNTPs, $20 \mathrm{pM}$ of each primer and $3.0 \mu \mathrm{L}$ of previously synthesized cDNA. The PCR was performed in a thermal cycler (Mastercycler Gradient, Eppendorf, Germany) in cyclic conditions: initial denaturation at $94{ }^{\circ} \mathrm{C}$ for 5 min, followed by 36 cycles of denaturation at $94{ }^{\circ} \mathrm{C}$ for $30 \mathrm{~s}$, annealing at $56^{\circ} \mathrm{C}$ for GRA and $45{ }^{\circ} \mathrm{C}$ for GRC) for $30 \mathrm{~s}, 72{ }^{\circ} \mathrm{C}$ for $45 \mathrm{~s}$ and final extension at $72{ }^{\circ} \mathrm{C}$ for $8 \mathrm{~min}$. The amplicons were analysed by electrophoresis on $1.5 \%$ agarose gel containing ethidium bromide $(0.5 \mu \mathrm{g} / \mathrm{mL})$ in Tris-borate buffer, visualized with a UV transilluminator and photographed by a gel documentation system (AlphaImager, USA).

Cloning and sequencing. The extracted PCR products were purified (QIAGEN kit) and cloned in TA cloning vector (MBI Fermentas) and sent for sequencing to a DNA sequencing facility, at the Department of Biochemistry, University of Delhi, South Campus, New Delhi, using an automated sequencer Excel Applied Biosystem 3730 
H. Kylla et al.: Detection and characterization of Genogroup 5 Rotavirus associated with piglet diarrhoea in the North East Region of India

(USA). Sequencing data were analysed using the MegAlign program. Phylogenetic and bootstrap analyses were performed using neighbor joining and seqboot programmes. Partial nucleotide sequences of isolates from the present study have been deposited in NCBI GenBank (Accession nos. KT032186, KT032187, KT032188 and KT032189).

\section{Results}

Prevalence of Rotavirus in piglets by RNA-PAGE. The overall prevalence of Rotavirus in piglets by RNA-PAGE was recorded as 4.81\% (22/457). Meghalaya showed the highest $(6.45 \%)$ prevalence, followed by Manipur (5.56\%), Mizoram (4.16\%), and Nagaland $(2.85 \%)$. The prevalence of Rotavirus was recorded higher in unorganized farms $(6.46 \%)$ compared to organized farms $(3.11 \%)$. Similarly, the rate of detection of Rotavirus from diarrhoeic animals was higher (5.89\%) than non-diarrhoeic animals $(1.69 \%)$ in all the states throughout the study period. The breed-wise analysis revealed that cross breed animals were more susceptible (5.50\%) than the local breed of animals (3.07\%) (Table 1).

Table 1. The prevalence of Group A rotavirus detected by RNA-PAGE from faecal samples of piglets in four NEH states of India

\begin{tabular}{|c|c|c|c|c|c|c|}
\hline State & \multicolumn{2}{|c|}{ Positive samples } & Diarrhoeic & $\begin{array}{c}\text { Non- } \\
\text { diarrhoeic }\end{array}$ & Local breed & Crossbreed \\
\hline \multirow{3}{*}{ Manipur } & Organized & $\begin{array}{c}2 / 46 \\
(4.35 \%)\end{array}$ & $\begin{array}{c}2 / 32 \\
(6.25 \%)\end{array}$ & $0 / 14$ & $0 / 4$ & $\begin{array}{c}2 / 42 \\
(4.76 \%)\end{array}$ \\
\hline & Unorganized & $\begin{array}{c}4 / 62 \\
(6.45 \%)\end{array}$ & $\begin{array}{c}3 / 46 \\
(6.52 \%)\end{array}$ & $\begin{array}{c}1 / 16 \\
(6.25 \%)\end{array}$ & $\begin{array}{c}1 / 24 \\
(4.16 \%)\end{array}$ & $\begin{array}{c}3 / 38 \\
(7.89 \%)\end{array}$ \\
\hline & Total & $\begin{array}{c}6 / 108 \\
(5.56 \%)\end{array}$ & $\begin{array}{c}5 / 78 \\
(6.41 \%) \\
\end{array}$ & $\begin{array}{c}1 / 30 \\
(3.33 \%) \\
\end{array}$ & $\begin{array}{c}1 / 28 \\
(3.57 \%) \\
\end{array}$ & $\begin{array}{c}5 / 80 \\
(6.25 \%) \\
\end{array}$ \\
\hline \multirow{3}{*}{ Meghalaya } & Organized & $\begin{array}{c}2 / 66 \\
(3.03 \%)\end{array}$ & $\begin{array}{c}2 / 48 \\
(4.17 \%)\end{array}$ & $0 / 18$ & $0 / 12$ & $\begin{array}{c}2 / 54 \\
(3.70 \%)\end{array}$ \\
\hline & Unorganized & $\begin{array}{c}6 / 58 \\
(10.34 \%)\end{array}$ & $\begin{array}{c}5 / 42 \\
(11.90 \%)\end{array}$ & $\begin{array}{c}1 / 16 \\
(6.25 \%)\end{array}$ & $\begin{array}{c}2 / 22 \\
(9.09 \%)\end{array}$ & $\begin{array}{c}4 / 36 \\
(11.11 \%)\end{array}$ \\
\hline & Total & $\begin{array}{c}8 / 124 \\
(6.45 \%)\end{array}$ & $\begin{array}{c}7 / 90 \\
(7.77 \%)\end{array}$ & $\begin{array}{c}1 / 34 \\
(2.94 \%)\end{array}$ & $\begin{array}{c}2 / 34 \\
(5.88 \%)\end{array}$ & $\begin{array}{c}6 / 90 \\
(6.66 \%) \\
\end{array}$ \\
\hline \multirow{3}{*}{ Mizoram } & Organized & $\begin{array}{c}2 / 57 \\
(3.51 \%)\end{array}$ & $\begin{array}{c}2 / 45 \\
(4.44 \%)\end{array}$ & $0 / 12$ & $0 / 14$ & $\begin{array}{c}2 / 43 \\
(4.65 \%)\end{array}$ \\
\hline & Unorganized & $\begin{array}{c}3 / 63 \\
(4.76 \%)\end{array}$ & $\begin{array}{c}3 / 52 \\
(5.77 \%)\end{array}$ & $0 / 11$ & $\begin{array}{c}1 / 26 \\
(3.85 \%)\end{array}$ & $\begin{array}{c}2 / 37 \\
(5.41 \%)\end{array}$ \\
\hline & Total & $\begin{array}{c}5 / 120 \\
(4.16 \%)\end{array}$ & $\begin{array}{c}5 / 97 \\
(5.15 \%) \\
\end{array}$ & $\begin{array}{c}0 / 23 \\
(0.0 \%)\end{array}$ & $\begin{array}{l}1 / 40 \\
(2.5 \%)\end{array}$ & $\begin{array}{c}4 / 80 \\
(5.0 \%)\end{array}$ \\
\hline \multirow{3}{*}{ Nagaland } & Organized & $\begin{array}{c}1 / 56 \\
(1.79 \%)\end{array}$ & $\begin{array}{c}1 / 38 \\
(2.63 \%)\end{array}$ & $0 / 18$ & $0 / 11$ & $\begin{array}{c}1 / 45 \\
(2.22 \%)\end{array}$ \\
\hline & Unorganized & $\begin{array}{c}2 / 49 \\
(4.08 \%)\end{array}$ & $\begin{array}{c}2 / 36 \\
(5.56 \%)\end{array}$ & $0 / 13$ & $0 / 17$ & $\begin{array}{c}2 / 32 \\
(6.25 \%)\end{array}$ \\
\hline & Total & $\begin{array}{c}3 / 105 \\
(2.85 \%)\end{array}$ & $\begin{array}{c}3 / 74 \\
(4.05 \%)\end{array}$ & $\begin{array}{c}0 / 31 \\
(0.0 \%)\end{array}$ & $\begin{array}{c}0 / 28 \\
(0.0 \%)\end{array}$ & $\begin{array}{c}3 / 77 \\
(3.89 \%)\end{array}$ \\
\hline \multicolumn{2}{|l|}{ Grand total } & $\begin{array}{c}22 / 457 \\
(4.81 \%)\end{array}$ & $\begin{array}{c}20 / 339 \\
(5.89 \%)\end{array}$ & $\begin{array}{c}2 / 118 \\
(1.69 \%)\end{array}$ & $\begin{array}{c}4 / 130 \\
(3.07 \%)\end{array}$ & $\begin{array}{c}18 / 327 \\
(5.50 \%)\end{array}$ \\
\hline
\end{tabular}


H. Kylla et al.: Detection and characterization of Genogroup 5 Rotavirus associated with piglet diarrhoea in the North East Region of India

Prevalence of Rotavirus in piglets by RT-PCR. A similar prevalence study was also recorded by RT-PCR. Details of the result are depicted in Table 2. The overall prevalence of Rotavirus based on RT-PCR was much higher (7.43\%, 34/457) than the RNA-PAGE $(4.81 \%, 22 / 457)$ analysis. All the positive samples were found to be within the Genogroup A Rotavirus only. Meghalaya showed the highest $(9.67 \%)$ prevalence, followed by Manipur (8.33\%), Mizoram (5.83\%) and Nagaland (7.43\%). The unorganized farms showed a higher prevalence $(10.77 \%)$ compared to the organized farms $(4.00 \%)$. The rate of detection of Rotavirus from diarrhoeic animals was higher $(9.14 \%)$ than nondiarrhoeic animals (2.54\%) in all the states throughout the study period. The breed-wise analysis also showed that cross breed animals were more susceptible $(8.25 \%)$ than the local breed of animals (5.38\%) (Table 2).

Table 2. The prevalence of Group A rotavirus detected by RT-PCR from faecal samples of piglets in four NEH states of India

\begin{tabular}{|c|c|c|c|c|c|c|}
\hline \multirow{3}{*}{$\begin{array}{l}\text { State } \\
\text { Manipur }\end{array}$} & \multicolumn{2}{|c|}{ Positive samples } & \multirow{2}{*}{$\begin{array}{c}\text { Diarrhoeic } \\
3 / 32 \\
(9.38 \%)\end{array}$} & \multirow{2}{*}{$\begin{array}{c}\begin{array}{c}\text { Non- } \\
\text { diarrhoeic }\end{array} \\
0 / 14\end{array}$} & \multirow{2}{*}{$\begin{array}{c}\text { Local breed } \\
0 / 4\end{array}$} & \multirow{2}{*}{$\begin{array}{c}\text { Crossbreed } \\
3 / 42 \\
(7.14 \%)\end{array}$} \\
\hline & Organized & $\begin{array}{c}3 / 46 \\
(6.52 \%)\end{array}$ & & & & \\
\hline & Unorganized & $\begin{array}{c}6 / 62 \\
(9.68 \%)\end{array}$ & $\begin{array}{c}5 / 46 \\
(10.87 \%)\end{array}$ & $\begin{array}{c}1 / 16 \\
(6.25 \%)\end{array}$ & $\begin{array}{c}2 / 24 \\
(8.33 \%)\end{array}$ & $\begin{array}{c}4 / 38 \\
(10.53 \%)\end{array}$ \\
\hline & Total & $\begin{array}{c}9 / 108 \\
(8.33 \%) \\
\end{array}$ & $\begin{array}{c}8 / 78 \\
(10.25 \%)\end{array}$ & $\begin{array}{c}1 / 30 \\
(3.33 \%) \\
\end{array}$ & $\begin{array}{c}2 / 28 \\
(7.14 \%) \\
\end{array}$ & $\begin{array}{c}7 / 80 \\
(8.75 \%) \\
\end{array}$ \\
\hline \multirow{3}{*}{ Meghalaya } & Organized & $\begin{array}{c}2 / 66 \\
(3.03 \%)\end{array}$ & $\begin{array}{c}2 / 48 \\
(4.16 \%)\end{array}$ & $0 / 18$ & $0 / 12$ & $\begin{array}{c}2 / 54 \\
(3.70 \%)\end{array}$ \\
\hline & Unorganized & $\begin{array}{c}10 / 58 \\
(17.24 \%)\end{array}$ & $\begin{array}{c}9 / 42 \\
(21.43 \%)\end{array}$ & $\begin{array}{c}1 / 16 \\
(6.25 \%) \\
\end{array}$ & $\begin{array}{c}3 / 22 \\
(13.64 \%)\end{array}$ & $\begin{array}{c}7 / 36 \\
(19.44 \%)\end{array}$ \\
\hline & Total & $\begin{array}{c}12 / 124 \\
(9.67 \%) \\
\end{array}$ & $\begin{array}{c}11 / 90 \\
(12.22 \%)\end{array}$ & $\begin{array}{c}1 / 34 \\
(2.94 \%) \\
\end{array}$ & $\begin{array}{c}3 / 34 \\
(8.82 \%) \\
\end{array}$ & $\begin{array}{c}9 / 90 \\
(10.0 \%) \\
\end{array}$ \\
\hline \multirow{3}{*}{ Mizoram } & Organized & $\begin{array}{c}2 / 57 \\
(3.51 \%)\end{array}$ & $\begin{array}{c}2 / 45 \\
(4.44 \%)\end{array}$ & $0 / 12$ & $0 / 14$ & $\begin{array}{c}2 / 43 \\
(4.65 \%)\end{array}$ \\
\hline & Unorganized & $\begin{array}{c}5 / 63 \\
(7.94 \%)\end{array}$ & $\begin{array}{c}4 / 52 \\
(7.69 \%)\end{array}$ & $\begin{array}{c}1 / 11 \\
(9.09 \%)\end{array}$ & $\begin{array}{c}1 / 26 \\
(3.85 \%)\end{array}$ & $\begin{array}{c}4 / 37 \\
(10.81 \%)\end{array}$ \\
\hline & Total & $\begin{array}{c}7 / 120 \\
(5.83 \%)\end{array}$ & $\begin{array}{c}6 / 97 \\
(6.18 \%)\end{array}$ & $\begin{array}{c}1 / 23 \\
(4.34 \%)\end{array}$ & $\begin{array}{l}1 / 40 \\
(2.5 \%)\end{array}$ & $\begin{array}{c}6 / 80 \\
(7.5 \%)\end{array}$ \\
\hline \multirow{3}{*}{ Nagaland } & Organized & $\begin{array}{c}2 / 56 \\
(3.57 \%)\end{array}$ & $\begin{array}{c}2 / 38 \\
(5.26 \%)\end{array}$ & $0 / 18$ & $0 / 11$ & $\begin{array}{c}2 / 45 \\
(4.44 \%)\end{array}$ \\
\hline & Unorganized & $\begin{array}{c}4 / 49 \\
(8.16 \%)\end{array}$ & $\begin{array}{c}4 / 36 \\
(11.11 \%)\end{array}$ & $0 / 13$ & $\begin{array}{c}1 / 17 \\
(5.88 \%)\end{array}$ & $\begin{array}{c}3 / 32 \\
(9.38 \%)\end{array}$ \\
\hline & Total & $\begin{array}{c}6 / 105 \\
(5.71 \%)\end{array}$ & $\begin{array}{c}6 / 74 \\
(8.10 \%)\end{array}$ & $\begin{array}{c}0 / 31 \\
(0.0 \%)\end{array}$ & $\begin{array}{c}1 / 28 \\
(3.57 \%)\end{array}$ & $\begin{array}{c}5 / 77 \\
(6.49 \%)\end{array}$ \\
\hline \multicolumn{2}{|l|}{ Grand Total } & $\begin{array}{c}34 / 457 \\
(7.43 \%)\end{array}$ & $\begin{array}{c}31 / 339 \\
(9.14 \%)\end{array}$ & $\begin{array}{c}3 / 118 \\
(2.54 \%)\end{array}$ & $\begin{array}{c}7 / 130 \\
(5.38 \%)\end{array}$ & $\begin{array}{c}27 / 327 \\
(8.25 \%)\end{array}$ \\
\hline
\end{tabular}


H. Kylla et al.: Detection and characterization of Genogroup 5 Rotavirus associated with piglet diarrhoea in the North East Region of India

Sequencing and phylogenetic analysis of the isolates. Representative samples from each state (Meghalaya, Manipur, Mizoram and Nagaland) of the NEH region of India were sequenced (VP7 gene region) (GenBank accession no. KT032189, KT032186, KT032187 and KT032188). On the basis of the nucleotide sequence analysis, all 4 isolates in this study belonged to the G5 genotype. All 4 isolates were grouped under one cluster but distinctly placed in the phylogenetic tree, and were not associated with any of the Indian isolates. Isolates from Meghalaya (KT032189) and Mizoram (KT032186) were identical, with 100\% sequence homology. No Indian isolates were closely related to the 4 isolates in the present study.

Season-wise prevalence of Rotavirus in North Eastern Hilly Region of India. The prevalence of Rotavirus in piglets of the NEH region of India is depicted in Table 3. The prevalence was significantly higher during summer $(12.50 \%)$ and winter $(9.09 \%)$ compared to the autumn (3.84\%) and spring (2.15\%).

Table 3. Season-wise prevalence of Group A rotavirus detected from faecal samples of piglets in four NEH states of India

\begin{tabular}{|l|c|c|}
\hline Season & No. of samples screened & No. of samples positive (\%) \\
\hline $\begin{array}{l}\text { Spring } \\
\text { (March - May) }\end{array}$ & 93 & $2(2.15 \%)$ \\
\hline $\begin{array}{l}\text { Summer } \\
\text { (June - August) }\end{array}$ & 128 & $16(12.5 \%)$ \\
\hline $\begin{array}{l}\text { Autumn } \\
\text { (September - November) }\end{array}$ & 104 & $4(3.84 \%)$ \\
\hline $\begin{array}{l}\text { Winter } \\
\text { (December - February) }\end{array}$ & 132 & $12(9.09 \%)$ \\
\hline Total & 457 & $34(7.43 \%)$ \\
\hline
\end{tabular}

\section{Discussion}

As depicted in Table 1 and Table 2, the prevalence of Rotavirus in young piglets in the NEH region of India was $7.43 \%$. The difference in prevalence by RNA-PAGE and RT-PCR is well established because RNA-PGE is a less sensitive technique in comparison to RTPCR for detection of RNA virus infection in the host (MALIK et al., 2014). The majority of previous researchers in different parts of the world recorded a higher prevalence of rotavirus in humans and/or animals (FEDOROVA et al., 2005; KUSUMAKAR et al., 2009) by RT-PCR than RNA-PAGE. The prevalence of Rotavirus in piglets is highly variable globally. In India, limited studies have been carried out on rotaviral infection in piglets. DUBAL et al. (2013) reported an overall prevalence of $10.18 \%$ GARV in piglets from different regions of India; in contrast, no Rotavirus was detected in diarrhoeal faecal samples from piglets in Bareilly and Pantnagar by RNA-PAGE and RT-PCR (KUMAR, 
2006). In central India, the incidence of porcine Rotavirus was found to be $25.71 \%$ in the swine population (KUSUMAKAR et al., 2009). The prevalence of porcine GARV infections in diarrhoeic piglets was reported to be $3.3 \%$ in Argentina (Parra et al. 2008), $4 \%$ in Southern Germany (WIELER et al., 2001), 22.3\% in Thailand (KHAMRIN et al., 2007), 35.3\% in Brazil (RACZ et al., 2000) and 38.3\% in South Korea (KIM et al., 2010).

In the present study, the incidence of Rotavirus in diarrhoeic animals $(9.14 \%)$ was much higher than in non-diarrhoeic animals (2.54\%) (Table 2). A higher prevalence of rotavirus from diarrheic animals was also reported by other researchers from India and other parts of the world, with a variable prevalence rate (DUBAL et al., 2013; GATTI et al., 1993; SAIKRUAND et al., 2012). Excretion of Rotavirus is usually associated with diarrhoea in piglets, both before and after weaning. Our findings also indicate that the virus survives even after a diarrhoeal episode of a few days. An in vivo study is required to discover the survivability of the virus and shedding in the faeces after experimental infection in a laboratory, as well as in domestic animals. Rotavirus is considered to be a primary pathogen associated with diarrhoea in humans and animals, and may also appear as a concomitant infection with other enteric pathogens, viz., Picobirnavirus, E. coli, Salmonella etc (MALIK et al., 2014). Therefore, recovery of a fairly high level of rotavirus from the diarrhoeic piglets in the present study definitely indicates its role in the development of diarrhoea in the host.

The prevalence of diarrhoea associated with Rotavirus is recorded to be higher in unorganized farms $(10.77 \%)$ compared to organized farms $(4.00 \%)$. This result may have a direct correlation with management practices. Rotaviruses can directly enter and be transmitted through water on the farm. Small and landless farmers with a handful of animals are not able to maintain proper hygiene practices on their own and this may be the reason why they attract viral pathogens on their farms. The prevalence of Rotavirus in cross breed animals is recorded to be higher (8.25\%) than local germ plasma (5.38\%). Although the variation is not very wide or significant it may be possible that the local nondescriptive animals possess better protective mechanisms against natural infection than exotic or cross breed animals. In addition, the weaning age of piglets of local animals is generally 8-10 weeks in comparison with cross breed animals on organized farms (within 6 weeks). Maternal immunity might also play an important role in resisting infection in piglets.

In the present study we also recorded the seasonal variations of Rotavirus infection in piglets in the NEH states of India. Interestingly, we recorded a wide variation between summer $(12.50 \%)$ and winter $(9.00 \%)$, and with spring $(2.15 \%)$ and autumn $(3.84 \%)$. Samples were collected consistently for 2 years from similar locations with similar frequency. The humid climatic conditions during summer and winter with persistent rainfall in this region of country may be an influential factor for the persistence and consistent spread of infection among the animals. The similar climatic conditions are 
also a favourable environment for other enteric pathogens such as E. coli, Salmonella, Picobirnavirus, and Coronavirus etc., which are considered to be common associated pathogens of Rotavirus for the development of diarrhoea in piglets. Our results are also in corroboration with the findings of other researchers (BORADE et al., 2010; DUBAL et al., 2013; KIM et al., 2010) who reported a higher prevalence of porcine GARV infections during the summer and winter. However, JEONG et al., (2009) in South Korea reported that the prevalence of porcine GCRVs was more common in the spring (44\%) and winter (36\%), which may be due to the maintenance of carrier animals in the herd.

All the positive samples in the present study exhibited the presence of Group A porcine Rotavirus and also within genogroup 5(G5). In India, only 4 G types (G4, G6, G9, G12) and $4 \mathrm{P}$ types (P[6], P[7], P[13], P[19]) of rotaviruses have been detected from pigs so far (MALIK et al., 2014). Hence, this is the first report of the detection of G5 Rotavirus from pigs in India. Worldwide reports and surveys have identified G3, G4, G5 and G11 as the most common $\mathrm{G}$ genotypes and $\mathrm{P}[6]$ and $\mathrm{P}[7])$ as the most common $\mathrm{P}$ genotypes associated with diarrhoea in pigs. Also rare genotypes (G1, G2-like, G6, G8, G9, G10, and G12) were reported in pigs, which are commonly associated with humans and cattle (ESTES, 2001; GOUVEA et al., 1994; MARTELLA et al., 2005; MATTHIJNSSENS et al., 2008; PAPP et al., 2013; PRABHA and VERGHESE, 2009; RAMOS et al., 1998; STEELE et al., 2004; VARGHESE et al., 2006). Reports on Rotavirus prevalence from the Indian subcontinent revealed that the most common G types (G1-4) and P types (P[4] and $\mathrm{P}[8]$ ) globally account for three quarters of all strains on the subcontinent (MALIK et al., 2014). In various studies, G1-4, G6, G8-10 and G12 were reported in the human population in India (BANERJEE et al., 2006; BROOR et al., 2003; DAS et al., 2002; RAMANI and KANG, 2007). An earlier report from Jammu and Kashmir, India, revealed G10 to be the predominant genotype of bovine Rotavirus (WANI et al., 2004), whereas MINAKSHI (1999) reported G10 and G6 genotypes of bovine Rotavirus from calf diarrhoea cases. However, DUBAL et al. (2013) reported G4 and G9 porcine Rotavirus isolates from the western part of India.

Sequence analysis of G5 Rotavirus in the present study exhibited $99.4 \%$ to $100 \%$ homology (Fig. 1) among the isolates, which indicates the wide circulation of a particular viral strain in this region of India. All the isolates were grouped under one cluster in the phylogenetic tree and showed closer identity with human isolates, particularly Chinese strains, than with porcine strains. Usually the rotaviruses are species-specific, there is a possibility of cross-species transmission. Various case studies worldwide and in India have indicated that infection in humans may be caused by animal rotaviruses. A close identity is often revealed between human and animal rotaviruses, when the genetic sequences are compared. The evolution of porcine rotaviruses, especially through the exchange of genomic segments between the different host specific rotaviruses, leads to the emergence of novel porcine strains with the capability to infect human beings. 
H. Kylla et al.: Detection and characterization of Genogroup 5 Rotavirus associated with piglet diarrhoea in the North East Region of India

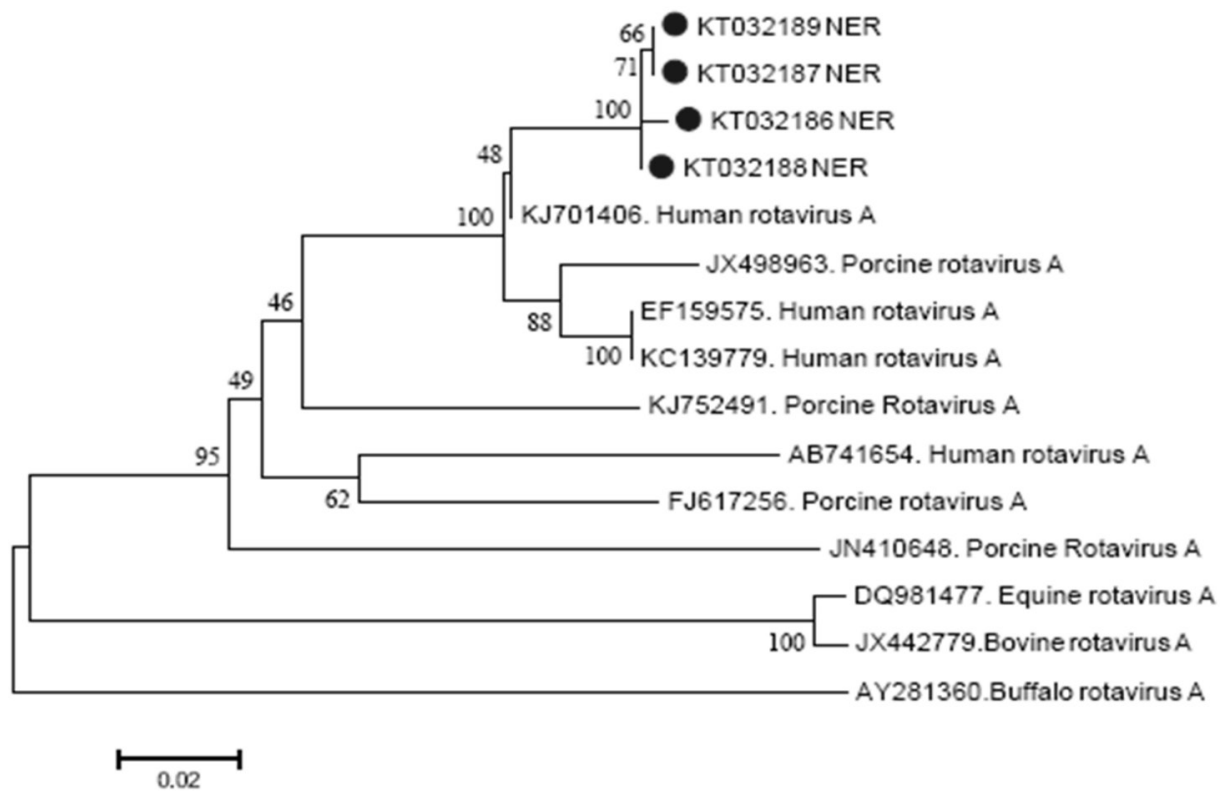

Fig. 1. Phylogenetic tree showing genetic relatedness of the Rotavirus isolated from piglets of 4 North Eastern hilly states of India and other Rotavirus isolates from humans and animals in India and other countries, based upon the nucleotide sequences of the VP7 gene region of GRA Rotavirus. All the 4 isolates in the present study are demarcated by a dot.

\section{Conclusion}

In conclusion it may be stated that rotaviruses are persistently associated with piglet diarrhoea in the NEH region of India. The prevalence of rotaviruses is high in the summer and winter seasons compared to the autumn and spring seasons, with a higher prevalence recorded in cross breed pigs compared to the local pigs. On the basis of sequence analysis, the isolates were found to be unique and placed in a separate cluster, and they are not closely associated with any other Indian isolates of rotaviruses found so far. All the isolates were under group A Rotavirus and under geno group 5. This is the first report on the prevalence of G5 rotaviruses associated with piglet diarrhoea in India. 
H. Kylla et al.: Detection and characterization of Genogroup 5 Rotavirus associated with piglet diarrhoea in the North East Region of India

\begin{abstract}
Acknowledgements
The authors are thankful to the Institutional Biotech Hub and ADMaC, Department of Biotechnology, Government of India and Dean, College of Veterinary Sciences \& Animal Husbandry for providing all the facilities to conduct the present work.
\end{abstract}

\title{
Conflicts of interest
}

The authors declare that they have no conflict of interest.

\section{References}

BANERJEE, I., S. RAMANI, B. PRIMROSE, P. MOSES, J. J. GRAY, S. JAFFAR, B. MONICA, J. P. MULIYIL, D. W. BROWN, M. ESTES, G. KANG (2006): Comparative study of the epidemiology of rotavirus in children from a community-based birth cohort and hospital in South India. J. Clin. Microbiol. 44, 2468-2474.

DOI: 10.1128/JCM.01882-05

BORADE, A., A. S. BAIS, V. BAPAT, R. DHONGADE (2010): Characteristic of rotavirus gastroenteritis in hospitalized children in Pune. Ind. J. Med. Sci. 64, 210-218.

BROOR, S., D. GHOSH, P. MATHUR (2003): Molecular epidemiology of rotaviruses in India. Ind. J. Med. Res. 118, 59-67.

CASTRO, A. E., W. P. HEUSCHELE (1992): Veterinary Diagnostic Virology. Mosby Year Book, Missouri.

CHAN, W. K., M. E. PENARADA, S. E. CRAWFORD, M. K. ESTES (1986): Two glycoproteins are produced from the rotavirus neutralization gene. Virol. 151, 243-252.

DOI: 10.1016/0042-6822(86)90046-2

DAS, S., A. SEN, G. UMA, V. VARGHESE, S. CHAUDHURI, S. K. BHATTACHARYA, T. KRISHNAN, P. DUTTA, D. DUTTA, M. K. BHATTACHARYA, U. MITRA, N. KOBAYASHI, T. N. NAIK (2002): Genomic diversity of Group A rota virus strains infecting humans in Eastern India. J. Clin. Microbiol. 40, 146-149.

DOI: 10.1128/JCM.40.1.146-149.2002

DUBAL, Z. B., K. N. BHILEGAONKAR, S. B. BARBUDDHE, R. P. KOLHE, S. KAUR, S. RAWAT, P. NAMBIAR, M. KARUNAKARAN (2013): Prevalence and genotypic (G and P) determination of porcine group A rotaviruses from different regions of India. Trop. Anim. Hlth. Prod. 45, 609-615.

DOI: $10.1007 / \mathrm{s} 11250-012-0267-1$

ESTES, M. K. (2001): Rotaviruses and their Replication. Fields Virology. 4 ed., (Knipe D. M., P. M. Howley, D. E. Grifun, R. A. Lamb, M. A. Martin, B. Roizman, S. Straus, E. Lipincott, Eds), William and Wilkins, Philadelphia, pp. 1747-1785.

FEDOROVA, O. F., N. A. NOVIKOVA, N. V. EPIFANOVA, L. B. LUKOVNIKOVA, O. N. KNIAGINA, E. V. GRACHEVA, E. M. BOGACHEVA (2005): Optimization of RT-PCR 
H. Kylla et al.: Detection and characterization of Genogroup 5 Rotavirus associated with piglet diarrhoea in the North East Region of India

for the identification of VP4 gene of Group A rotaviruses andevaluation of its diagnostic efficiency. Vopr. Virusol. 50, 39-41.

GABBAY, Y. B., A. A. BORGES, D. S. OLIVERIA, A. C. LINHARES, J. D. MASCARENHAS, C. R. BARARDI, C. M. SIMOES, Y. WANG, R. I. GLASS, B. JIANG (2008): Evidence for zoonotic transmission of group $\mathrm{C}$ rotaviruses among children in Belem, Brazil. J. Med. Virol. $80,1666-1674$.

DOI: $10.1002 / j m v .21250$

GATTI, M. S., M. M. FERRAZ, M. L. RÁCZ, A. F. DE CASTRO (1993): Rotavirus excretion in naturally infected pigs with and without diarrhoea. Vet. Microbiol. 37, 187-190. DOI: 10.1016/0378-1135(93)90193-B

GOUVEA, V., N. SANTOS, M. C. TIMENETSKY (1994): Identification of bovine and porcine rotavirus G types by PCR. J. Clin. Microbiol. 32, 1338-1340.

HALAIHEL, N., R. M. MASÍA, M. FERNANDEZ-JIMENEZ, J. M. RIBES, R. MONTAVA, I. DE BLAS, O. GIRONES, J. L. ALONSO, J. BUESA: (2010). Enteric calicivirus and rotavirus infections in domestic pigs. Epidemiol. Infec. 138, 542-548.

DOI: $10.1017 /$ S0950268809990872

JEONG, Y. J., S. I. PARK, M. HOSMILLO, D. J. SHIN, Y. H. CHUN, H. J. KIM, H. J. KWON, S. Y. KANG, S. K. WOO, S. J. PARK, G. Y. KIM, M. I. KANG, K. O. CHO (2009): Detection and molecular characterization of porcine group $\mathrm{C}$ rotaviruses in South Korea. Vet. Microbiol. 138, 217-224.

DOI: $10.1016 /$ j.vetmic.2009.03.024

JUNAID, S. A., C. UMEH, A. O. OLABODE, J. M. BANDA (2011): Incidence of rotavirus infection in children with gastroenteritis attending JOS University teaching hospital, Nigeria. Virol. J. 8, 233.

DOI: $10.1186 / 1743-422 X-8-233$

KHAMRIN, P., N. MANEEKARN, S. PEERAKOME, W. CHAN-IT, F. YAGYU, S. OKITSU, H. USHIJIMA (2007): Novel porcine rotavirus of genotype $\mathrm{P}$ [27] shares new phylogenetic lineage with G2 porcine rotavirus strain. Virol. 361, 243-252.

DOI: $10.1016 /$ j.virol.2006.12.004

KIM, H. J., S. I. PARK, HA T. P. MAI, Y. J. JEONG, H. H. KIM, H. J. KWON, M. I. KANG, K. O. CHO, S. J. PARK (2010): Detection and genotyping of Korean porcine rotaviruses. Vet. Microbiol. 144, 274-286.

DOI: 10.1016/j.vetmic.2010.01.019

KUMAR, M. (2006): Polymerase chain reaction for rapid detection of important zoonotic diarrhoeal pathogens. MVSc Thesis, Submitted to Deemed University, Indian Veterinary Research Institute, Izatnagar, Bareilly, India

KUSUMAKAR, A. L., SAVITA, Y. P. S. MALIK, P. G. MINAKSHI (2009): Occurrence of mammalian group A rotavirus in swine population of Central India. Ind. J. Anim. Sci. 78, 475-477.

Vet. arhiv 88 (4), 453-466, 2018 
H. Kylla et al.: Detection and characterization of Genogroup 5 Rotavirus associated with piglet diarrhoea in the North East Region of India

LiNARES, R. C., A. F. BARRY, A. F. ALFIERI, K. C. MEDiCI, C. FERronATO, W. GRIEDER, A. A. ALFIERI (2009): Frequency of group A rotavirus in piglet stool samples from non-vaccinated Brazilian pig herds. Brazilian Arc. Biol. Tec. 52, 63-68.

DOI: $10.1590 /$ S1516-89132009000700009

LORROT, M., M. VASSEUR (2007): How do the rotavirus NSP4 and bacterial enterotoxins lead differently to diarrhea. Virol. J. 4, 31.

DOI: $10.1186 / 1743-422 \mathrm{X}-4-31$

MALIK, Y. P. S., N. KUMAR, K. SHARMA, S. SIRCAR, K. DHAMA, D. P. BORA, T. K. DUTTA, M. PRASAD, A.K. TIWARI (2014): Rotavirus diarrhea in piglets: A review on epidemiology, genetic diversity and zoonotic risks. Ind. J. Anim. Sci. 84, 1035-1042.

MARTELLA, V., K. BANYAI, E. LORUSSO (2007): Prevalence of group C rotaviruses in weaning and post-weaning pigs with enteritis. Vet. Microbiol. 123, 26-33.

DOI: $10.1016 /$ j.vetmic.2007.03.003

MARTELLA, V., M. CIARLET, R. BASELGA, S. ARISTA, G. ELIA, E. LORUSSO, K. BÁNYAI, V. TERIO, A. MADIO, F. M. RUGGERI, E. FALCONE, M. CAMERO, N. DECARO, C. BUONAVOGLIA (2005): Sequence analysis of the VP7 and VP4 genes identifies a novel VP7 gene allele of porcine rotaviruses, sharing a common evolutionary origin with human G2 rotaviruses. Virol. 337, 111-113.

DOI: $10.1016 /$ j.virol.2005.03.031

MATTHIJNSSENS, J., M. CIARLET, M. RAHMAN, H. ATTOUI, K. BÁNYAI, M. K. ESTES, J.R. GENTSCH, M. ITURRIZA-GÓMARA, C. D. KIRKWOOD, V. MARTELLA, P.P. MERTENS, O. NAKAGOMI, J. T. PATTON, F. M. RUGGERI, L. J. SAIF, N. SANTOS, A. STEYER, K. TANIGUCHI, U. DESSELBERGER, M. VAN RANST (2008): Recommendations for the classification of group A rotavirus using all 11 genomic RNA segments. Arch. Virol. 153, 1621-1629.

DOI: $10.1007 / \mathrm{s} 00705-008-0155-1$

MATTHIJNSSENS, J., M. CIARLET, S. M. McDONALD, H. ATTOUI, K. BANYAI, J. R. BRISTER, J. BUESA, M. D. ESONA, M. K. ESTES, J. R. GENTSCH, M. ITURRIZAGOMARA, R. JOHNE, C. D. KIRKWOOD, V. MARTELLA, P. P. MERTENS, O. NAKAGOMI, V. PARRENO, M. RAHMAN, F. M. RUGGERI, L. J. SAIF, N. SANTOS, A. STEYER, K. TANIGUCHI, J. T. PATTON, U. DESSELBERGER, M. VAN RANST (2011): Uniformity of rotavirus strain nomenclature proposed by the Rotavirus Classification Working Group (RCWG). Arch. Virol. 156,1397-1413.

DOI: $10.1007 / \mathrm{s} 00705-011-1006-\mathrm{z}$

MINAKSHI (1999): Relative frequencies of G (VP7) and P (VP4) genotypes of group A rotavirus from diarrhoeic bovine calves by RT-PCR and their restriction endonuclease profile. Ph.D Thesis, Chaudhary Charan Singh, Haryana Agricultural University, Hisar, India. 
H. Kylla et al.: Detection and characterization of Genogroup 5 Rotavirus associated with piglet diarrhoea in the North East Region of India

PAPP, H., B. LASZLO, F. JAKAB, B. GANESH, S. DE GRAZIA, J. MATTHIJNSSENS, M. CIARLET, V. MARTELLA, K. BANYAI (2013): Review of group A rotavirus strains reported in swine and cattle. Vet. Microbiol. 165, 190-199.

DOI: 10.1016/j.vetmic.2013.03.020

PRABHA, S., S. VERGHESE (2009): Detection of porcine rotavirus from tissue and faecal specimens. Ind. J. Med. Microbiol. 27, 149-152.

DOI: $10.4103 / 0255-0857.49430$

RACZ, M. L., S. S. KROEFF, V. MUNFORD, T. A. CARUZO, E. L. DURIGON, Y. HAYASHI, V. GOUVEA, E. A. PALOMBO (2000): Molecular characterization of porcine rotaviruses from the southern region of Brazil: characterization of an atypical genotype G[9] strain. J. Clin. Microbiol. 38, 2443-2446.

RAMANI, S., P. KANG (2007): Burden of disease and molecular epidemiology of group A rotavirus infections in India. Ind. J. Med. Res. 125, 619-622.

RAMOS, A. P. D., C. C. STEFANELLI, R. E. C. LINHARES, B. G. BRITO, C. M. NOZAWA (1998): The infectivity of pig rotavirus in stools. Braz. J. Vet. Res. Anim. Sci. 35, 84-87.

DOI: $10.1590 /$ S1413-95961998000200007

SAIF, L. J., B. JIANG (1994): Non-group A rotaviruses of human and animals. Cur. Topics Microbiol. Immunol. 185, 339-371.

DOI: $10.1007 / 978-3-642-78256-5 \_11$

SAIKRUAND, W., P. KHAMRIM, N. CHAIMONGKOL, B. SUANTAI, A. KONGKAEWB, S. KONGKAEWC, H. USHIJIMA, N. MANEEKARN (2012): Genetic diversity and novel combinations of G4P[19] and G9P[19] porcine rotavirus strains in Thailand. Vet. Microbiol. $161,255-262$.

DOI: 10.1016/j.vetmic.2012.07.036

STEELE, A. D., A. GEYER, G. H. GERDES (2004): Rotavirus infections. In: Infectious Diseases of Livestock. (Coetzer, J. A.W., R. C. Tustin, Eds.) Oxford University Press, Southern Africa, pp. 1256-1264.

VARGHESE, V., S. GHOSH, S. DAS, S. K. BHATTACHARYA, T. KRISHNAN, P. KARMAKAR, N. KOBAYASHI, T. N. NAIK (2006): Characterization of VP1, VP2 and VP3 gene segments of a human rotavirus closely related to porcine strains. Virus Genes. 32, 241-247.

DOI: $10.1007 / \mathrm{s} 11262-005-6908-\mathrm{y}$

WAKUDA, M., T. IDE, J. SASAKI, S. KOMOTO, J. ISHII, T. SANEKATA, K. TANIGUCHI (2011): Porcine rotavirus closely related to novel group of human rotaviruses. Emerging Infec. Dis. 17, 1491-1493.

DOI: $10.3201 /$ edi1708.101466

WANI S, A., M. A. BHAT, S. M. ISHAQ, M. A. ASHRAFI (2004): Determination of bovine rotavirus G genotypes in Kashmir, India. Revue Scientifique Technique 23, 931-936.

DOI: 10.20506/rst.23.3.1538

WIELER, L. H., A. ILIEFF, W. HERBST, C. BAUER, E. VIELER, R. BAUERFEIND, K. FAILING, H. KLOS, D. WENGERT, G. BALJER, H. ZAHNER (2001): Prevalence of 
H. Kylla et al.: Detection and characterization of Genogroup 5 Rotavirus associated with piglet diarrhoea in the North East Region of India

enteropathogens in suckling and weaned piglets with diarrhoea in Southern Germany. J. Vet. Med. Infec. Dis. Vet. Public. Hlth. 48, 151-159.

DOI: 10.1046/j.1439-0450.2001.00431.x

WILHELMI, I., E. ROMAN, A. SANCHEZ-FAUQUIER (2003): Viruses causing gastroenteritis. Clin. Microbiol. Infec. 9, 247-262.

DOI: 10.1046/j.1469-0691.2003.00560.x

WINIARCZYK, S., P. S. PAUL, S. MUMMIDI, R. PANEK, Z. GRADZKI (2002): Survey of porcine rotavirus $\mathrm{G}$ and $\mathrm{P}$ genotype in Poland and the United States using RT-PCR. J. Vet. Med. Infec. Dis. Vet. Public. Hlth. 49, 373-378.

DOI: 10.1046/j.1439-0450.2002.00572.x

YANG, H., E. V. MAKEYEV, Z. KANG, S. JI, D. H. BAMFORD, A. A. VAN DIJK (2004): Cloning and sequence analysis of dsRNA segments 5, 6 and 7 of a novel non-group A, B, $\mathrm{C}$ adult rotavirus that caused an outbreak of gastroenteritis in China. Virus. Res. 106, 15-26.

DOI: 10.1016/j.virusres.2004.05.011

Received: 13 June 2017

Accepted: 17 December 2017

KYLLA, H., T. K. DUTTA, P. ROYCHOUDHURY, R. MANDAKINI, P. K. SUBUDH: Otkrivanje i karakterizacija rotavirusa genogrupe 5 povezanog $\mathrm{S}$ proljevom prasadi u sjeveroistočnoj Indiji. Vet. arhiv 88, 453-466, 2018.

\section{SAŽETAK}

Rotavirusi su prepoznati kao važan etiološki čimbenik nebakterijskog akutnog gastroenteritisa kod male djece i različitih vrsta životinja. Kod prasadi to uključuje i proljev koji se pojavljuje pri odbiću i nakon odbića. U ovom je radu prikazana prevalencija i molekularna epidemiologija rotavirusa otkrivenih kod prasadi iz različitih dijelova sjeveroistočnog, brdovitog područja Indije. U razdoblju od srpnja 2013. do lipnja 2015. godine, tijekom različitih sezona, prikupljeno je ukupno 457 uzoraka fecesa (339 proljevastih i 118 neproljevastih). Uzorci su potjecali od prasadi lokalnih $(\mathrm{n}=130)$ i križnih pasmina $(\mathrm{n}=327)$. Svi su uzorci podvrgnuti RNA-PAGE i RT-PCR analizama. Rotavirusi su otkriveni u 4,81 \% životinja pomoću RNA-PAGE i 7,43 \% životinja pomoću RT-PCR analize. Najveća prevalencija $(9,67 \%)$ utvrđena je u državi Meghalaya. Svi su izolati registrirani kao GARV i genogrupa 5. Prevalencija je bila viša u slabo organiziranim farmama (10,77 \%) u usporedbi s dobro organiziranim farmama $(4,0 \%)$, s većom učestalošću otkrivanja kod životinja koje su imale proljev $(9,14 \%)$ u odnosu na životinje bez proljeva (2,54 \%). Također, veća je prevalencija utvrđena tijekom ljetnih $(12,5 \%)$ i zimskih $(9,09 \%)$ sezona. Na temelju analize sekvencija svi su izolati smješteni u jedinstveni pojedinačni skup (klaster). Taj je skup različit od drugih indijskih izolata ljudi i životinja u kojima je bio u neposrednoj blizini izolata ljudi. Ovo je prvo izvješće o otkrivanju rotavirusa G5 povezanih s proljevom prasadi u Indiji.

Ključne riječi: rotavirus; prevalencija; Indija; genogrupa 5; prasad 